Peter Madsen

\title{
Modsigelsens poetik
}

\author{
Indledning. \\ 1. New Criticism. 'Den tilsyneladende disharmoni'. \\ 1.1. Oplevelsen af det mangfoldige menneske \\ 1.2. Poesiens kanonisering \\ 1.3. Digtet som iscenesæettelse \\ 2. Kritisk dialektik. Poesien, kulturindustrien og samfundet. \\ 2.1. Oplysningens dialektik \\ 2.2. Digtningen og sproget \\ 2.3. Integrationen og den lykkelige bevidsthed \\ 3. Tekst-teori. Sproget som generator. \\ 3.1. Teksten som paragram \\ 3.2. Det poetiske sprogs uendelighed og dens paragrammatiske praksis \\ Konklusion.
}

Som grundlag for enhver litteraturkritisk eller -pædagogisk praksis ligger en opfattelse af 'litteratur', et mere eller mindre eksplicit og eksplicitérbart begreb om, hvad det er for et emne der behandles. Gennem en eksplicitering af disse begreber kan en kritik af fremherskende typer pædagogisk-ideologisk praksis i forbindelse med litteratur funderes bedre end gennem blot og bar afvisning af enkelte eksempler.

'Litteratur' indtager en ikke ubetydelig plads i dannelseshierarkiet; derfor har det en interesse ud over det rent litterære felt at fremdrage sådanne opfattelser til diskussion.

Ofte er det ved at stille spørgsmålet om den enkelte kritiske holdnings grundlæggende begreb om det særligt litterære, det særligt poetiske osv, man kan nă frem til centrale ideologiske styringer af den kritiske praksis. Spørgsmålet om litteraturens 'litteraritet', det specifikt litterære, blev stillet af de russiske formalister på en sådan måde, at det stødte an mod den fremherskende litteraturopfattelse flere steder (således ved formalismens indførelse $\mathrm{i}$ fremmede miljøer). Årsagen til det skal nok søges i formalisternes afvisning af beskæftigelse med tekst-eksterne forhold, hvorved biografismens og åndshistoriens emner trådte ud af synsfeltet. Siden er formalismen dog på forskellig måde blevet integreret $\mathrm{i}$ litteraturkritikken, af Wellek formidlet med den amerikanske ny-kritik, af Todorov introduceret $i$ den franske debat. Bredt sagt løber disse tendenser sammen $i$ koncentrationen om 'teksten selv', hvorved de placerer sig i den indtil for nylig fremherskende autonomiserings-tendens, som kan genfindes i en række videnskaber - eksemplarisk i sprogvidenskaben, hvis strukturelle 
udgave da også har givet inspiration til litteraturvidenskaben. Kritikken af 'autonomismen' har siden antaget to former, dels kritik 'udefra', dels forsøg pá opbrydning 'indefra', dette kan antagelig siges at gælde såvel sprogvidenskaben som litteraturvidenskaben. Begge aspekter er nødvendige led $i$ udviklingen af en tekst-videnskab, der forstår sit emne i dets sammenfletning med den samfundsmæssige helhed. Koncentrationen om teksten selv har tilført litteraturvidenskaben en række erkendelser om tekstlige forhold, som den tidligere kritik enten ikke eller kun sporadisk besad, men i sig selv har 'autonomismen' ofte - blot mere tilsløret reproduceret opfattelser, som også lå til grund for tidligere strømninger i litteraturvidenskaben (introduktioner og kritik i Madsen 1967, 1969 og 1971a).

I det første afsnit af det følgende vil jeg vise, hvordan der bag et eksempel på angel-saksisk ny-kritik ligger ganske traditionelle begreber om litteratur som udtryk for fyldig opfattelse af Mennesket, samtidig med at der ligger begreber om tekstens funktionsmåde, som vil kunne integreres og er ved at blive integreret - i kritisk litteratur-analyse. Det næste afsnit vil vise, hvordan en kritiker som Theodor W. Adorno med sit begreb om den digteriske teksts relative autonomi $\mathrm{i}$ forhold til den forhåndenværende samfundstilstand og derudaf vokset sprogbrug giver mulighed for kritik af den umiddelbart eller middelbart lighedssøgende (hermeneutiske) læsning af teksterne til fordel for en læsning, der ser teksterne som i sig selv kritiske. Såvel Brooks, der benyttes som eksempel på New Criticism, som Adorno arbejder med begreber om modsigelser i de poetiske tekster, men på fundamentalt forskellig vis. Ligheder og forskelle i deres modsigelsesbegreber kan da centralt vise de to opfattelsers forskellighed. Endelig vil jeg på denne baggnund diskutere Julia Kristevas begreber om tekstlige fænomener, hvorunder netop det poetiske sprogs særlige funktion som sprogkritik og dermed ideologi-kritik.

\section{NEW CRITICISM. Den tilsyneladende disharmoni}

Lad os tale kort her til metaforens pris.

Wimsatt \& Brooks

Metaforen er poesiens essens. . .

Brooks

\subsection{Oplevelsen af det mangfoldige menneske}

Der er her ikke nødvendigvis tale om 'nykritik som sådan' eller om 'det typisk nykritiske', men om et tema, som jeg mener fremtræder i nogle 


\section{6}

nykritiske tekster. Ikke blot dér, men også $\mathfrak{i}$ andre typer nyere kritik (og ældre). For så vidt forekommer temaet mig at have interesse. En yderligere bevæggrund er, at temaet gennem en omstrukturering, gennem en historisk formidlet forståelse, kan bringes i forbindelse med et vigtigt tema i marxistisk kritik, eller præcisere: i en del marxistisk kritik. Det drejer sig om et tema, som formelmæssigt kan benævnes som 'den tilsyneladende disharmoni', eller 'digtningen som ophævelse eller beherskelse af oplevede modsætninger'. Omfortolkningen kan benævnes: 'digtning som formulering af oplevet modsætning', eller: 'digtning som (potentiel) kritik af herskende tilstande'.

For dog ikke helt at føre diskussionen løsrevet fra kanoniske nykritikere vil jeg benytte Cleanth Brooks som eksempel (idet det bemærkes at min pointe ikke nødvendigvis er at kritisere Brooks som sådan, d.v.s. som Brooks, men at fremhæve et synspunkt, som i hvert fald kan læses ud af passager hos Brooks og som jeg vil postulere ofte træder frem i diskussioner om digtning).

Der er i Brooks' billede af 'poesiens essens' involveret dels det kendte syn, at 'form' og 'indhold', 'struktur' og 'holdning' skal stemme overens de anvendte 'devices' skal være i overensstemmelse med værkets, digtets, 'structure of attitudes', dels den ikke mindre kendte opfattelse, at digtning ikke - hvis det er god digtning - er éntydig, men tværtimod afviser en bestemt holdning til fordel for en fremstilling, som impliceres indbyrdes modstridende holdninger, hvis modstrid ophæves gennem det særligt digteriske i behandlingen.

Dette synspunkt kan naturligvis ikke fastholdes in abstracto. Bag det ligger et menneskesyn, som antydningsvis kan fremstilles som på én gang afvisningen af det enkle og fastholdelse af enhed. Sandheden om mennesket (livet og døden osv) er ikke éntydig; hvis ét synspunkt fremhæves, så må også dets modsætning fremdrages. Pointen er dog ikke, at der ingen enhed er, eftersom det sandt menneskelige netop er énheden i denne tilsyneladende mangfoldighed; poesiens særlige funktion fremtræder her: nemlig den sprogligt at fastholde denne enhed $i$ mangfoldigheden.

Derved får poesien også sin særlige mission, nemlig den i en tid, der er domineret af praktisk og videnskabelig tænkning, altså ensidig satsen på det praktisk rationelle, at være den instans, som fastholder og formidler det sandt menneskelige. Gennem poesien bæres Menneskets mangfoldighed og derved Menneskets énhed gennem historien og den har bud ikke mindst til netop vor tids mennesker.

Det her skitsemæssigt fremstillede poesisyn er ikke umiddelbart ahistorisk, eftersom den bestemte ensidighed som et givet værk reagerer på og 'supplerer' er historisk bestemt gennem den historisk bestemte kultur og det historisk-kulturelt bestemte sprog. Men poesisynet er dog ahistorisk for så vidt poesiens essentielle funktion netop er at ophave det historisk 
bestemte og indoptage det i den altomfattende menneskelighed, som da skal opleves af poesi-læseren. Det er sảledes en rent bevidsthedsmæssig 'Aufhebung' der er tale om. Gennem læsningen møder læseren en bestemt - historisk bestemt - reaktion på og bearbejdning af en ikke mindre historisk bestemt holdning; den historisk bestemte læser drages da gennem sin læsning af den historisk bestemte poesi ind $\mathrm{i}$ den ahistoriske altomfattende Menneskelighed, som det er poesiens essentielle funktion og mission at formidle hen gennem historien. Gennem læsningen får læseren mulighed for at opleve sig selv og sine medmennesker $\mathrm{i}$ al den fylde, som det på grund af den faktiske historiske placering ikke er muligt for ham at leve i. Kritikeren bliver den formidlende interpret, der påpeger på én gang poesiens og menneskets essens. Han er som præsten, der gennem sit eget og skriftens ord bringer menigheden $i$ forbindelse med den over historien og $i$ Bibelens historier svævende Logos. Fra den digteriske ånds ophævelse of den historiske udgangssituation til den åndfulde læsnings ophævelse af læserens historiske situation forbliver digtning således en luftig affære.

Men i stedet for at fastholde dette poesisyn på dets historiophævende tendens kunne man tage udgangspunkt $\mathrm{i}$ den historicitet, som der faktisk også er tale om; man kunne overveje, om der ikke går en anden vej fra den udgangskonstatering, at f.eks. noget moderne poesi er en art protest imod eksklusivt praktisk og videnskabelig udnyttelse af bevidsthedsmæssigt potentiel. Der er netop et sted hos Brooks tale om poesi som overskridelse af 'det begrænsede og specielle syn, som anlægges i praktisk og videnskabelig tale'. Problemet er da så at sige om man gennem denne overskridelse skrider ud af historien eller ind i den. Det første er tilfældet, hvis den vej, som jeg netop har skitseret følges; men ind i historien kommer man, hvis begrænsningen fastholdes som faktisk - udsprunget af faktiske konflikter - og ikke blot som tankeform.

Jeg antydede før modsætningeri mellem en oplevet 'fylde' og en levet 'fylde'; den oplevelse, som poesilæsningen lægger op til er uden praktiske konsekvenser, fordi den vender ryggen til alle andre dele af verden end den private oplevende bevidsthed, den tager ikke hensyn til den oplevendes færden i den verden, hvis begrænsning digtningen påpeger og kritiserer, den er kontemplativ. I stedet for at sætte problemet som et spørgsmål om at komme ud over interessen for praksis, kunne behovet for en alternativ praksis fremdrages af digtningens kritik af begrænsning. En sådan alternativ praksis vil ofte vise sig at være højst upraktisk for dem, i hvis interesse den fremherskende praksis er. Fra at være en blot og bar kritik af den instrumentelle fornuft (en sådan kritik ligger implicit og til dels eksplicit i en del af f.eks. Brooks kritik), kunne litteraturen og litteraturkritikken således gå hen og blive en kritik af de forhold, hvis tankemæessige fremtrædelsesform den instrumentelle fornuft er. Så ville beskæftigelse med litteratur kunne blive historisk handling, ganske vist stadig af 
178

åndeligt-luftig art (som al kritik), men dog med en (ind)retning, som ikke peger bort fra historien og ind i en de dannedes rækken hinanden $(h) a ̊ n d e n$ tværs over historien i en menneskenes Menneskeligheds sfære.

Sat på formel: det må dreje sig om at gøre det samfundsmæssige liv menneskeligt, og ikke blot opleve den menneskelighed som ingen plads har i virkeligheden.

\subsection{Poesiens kanonisering}

Brooks' analyse af John Donne's "The Canonization" kan benyttes som eksempel. "The Language of Paradox" er titlen på forste kapitel i The Well Wrought Urn (1963, på dansk Poetik struktur 1968) og analysen søger da også bl.a. gennem analyse af digtets sproglige fænomener at nå frem til dets paradoksale mening og dets mening som paradoks.

Gangen i digtet kan ganske kort gengives således: En elsker henvender sig til en ven el. lign., der håner hans optagethed af kærligheden; elskeren opfordrer vennen til at soge tilfredsstillelse $i$ samfundslivet og overlade ham til kærlighedslykken, som jo ikke kan genere samfundslivet. De elskende er som Fugl Fønix, deres kærlighed er stadigt genopblussende; er de ikke værdige store, prangende mindesmærker eller helgenlegender, så vil de dog finde deres plads i digte og som mønstergyldige helgener kan kommende elskovspar tilbede og anråbe dem.

Brooks tager udgangspunkt i det (tilsyneladende) paradoks, at enten må digteren tage religionen alvorligt og da er sammenstillingen utilbørlig, eller han må tage kærligheden alvorligt, og da er hans vittige ordspil (hans 'wit') parodierende. Det er da Brooks' opfattelse, at digtet tager såvel kærligheden som religionen alvorligt, således at paradokset faktisk kun er tilsyneladende :

en læsning af digtet vil vise, at Donne tager både kærlighed og religion alvorligt; den vil vise, at paradokset her er et uundværligt redskab. (Brooks 1968, 18; 11).

De første to strofer viser modsætningen mellem de to dialogpartneres idealer, sådan som det ser ud for den elskende:

... Take you a course, get you a place,

Observe his honour, or his grace,

Or the King's real, or his stamped face

Contemplate, what you will, approve,

So you will let me love.

(... Find dig en bane, få en plads, sku hans højhed eller hans nåde, betragt kongens eget eller hans prægede ansigt, anerkend hvad du vil, blot du lader mig elske). 
Den elskende opgiver gerne den verden, hvori opmærksomheden fæstnes på kongen eller kongeportrættet på mønten, og omvendt griber den elskendes liv ikke ind i samfundslivet:

Alas, alas, who's injur'd by my love?

What merchants ships have my sighs drown'd?

(Ak, ak, hvem skades af min kærlighed? Hvis handelsskib er sunket ved mit suk?).

Her bemærker Brooks selve formuleringen og billedet; den petrarchistiske traditions elaborerede udtryk for kærlighed drives her så langt ud, at de samtidig med at de indgår $i$ en betydende sammenhæng - mister deres gængse betydning:

Deri ligger, at digteren selv erkender det absurde i de petrarchiske kærlighedsmetaforer (op. cit. 19; 13).

Denne kombinerede brug og parodiering af den overleverede formulering fortsættes, men ophæves også i tredje strofe, hvor de elskende sammenlignes med Fugl Fønix; fra den negative afvisning af den ydre verdens krav går digtet over i den positive sætten af kærlighedens gerninger:

The Phoenix riddle have more wit by us. . .

(Fønix-gåden bliver mere vis ved os. ..).

Når der opresumeres:

We can die by it if not live by love,

(Vi kan dø om ikke leve af kærlighed. ..).

så anvendes ordspillet på 'die' (dø - nyde den seksuelle udløsning) til at sæt te skellet mellem de elskendes interesser og samfundets.

Og gennem digtets kanonisering af de elskende når det frem til at tage alt det igen, som blev forsaget i begyndelsen; forst er de elskende - med religiøs overbygning - hinandens eneboerhytte: og derved ophæves jo den for helgener hyppige seksuelle forsagelse, dernæst giver de elskende hver hinanden en hel verden:

... Who did the whole world's soule contract, and drove

Into the glasses of your eyes

[...]

Countries, Townes, Courts. . .

(Som sammendrog den hele verdens sjæl, og drev ind i jeres øjnes spejl

[...] lande, byer, hoffer. ..).

Igennem den her refererede analyse er Brooks kommet fra det oprindelige paradoks (religiøsitet vs erotik) til 
[...] en afsluttende komplicitet. De to elskende opnår i virkeligheden den mest intense form for liv ved at give afkald på dette liv. Dette paradoks er antydet tidligere, i Fugl Fønix-metaforen Her blir den virkningsfuldt dramatiseret (op. cit. $21 ; 15$ ).

Brooks viser, hvordan Donne's wit spiller på Fønix-billedet:

Sammenligningen mellem de to elskende og Fugl Fønix hører nøje sammen med de to tidligere sammenligninger; den, hvor de elskende sammenlignes med brændende kerter, og den, hvor de er lig en ørn og en due. Fugl Fønix-sammenligningen fastholder begge: Fugl Fønix er en fugl, der brænder, ligesom kerter (op. cit. $21 ; 15$ ).

Digtet munder ud i et "brilliant paradox" (17), som (op)løser modsætningerne $\mathrm{i}$ digtet, men Brooks går videre til at bestemme digtets centrale tematik som søgen efter enhed (hvilket må implicere søgen efter opløsning af modsætninger):

For os idag forekommer Donne's forestillinger (imagination) besat af enheds-problemet; den måde på hvilken (the sense in which) de elskende bliver ét - den måde på hvilken sjælen forenes med Gud. Som vi har set bliver den ene type forening ofte metafor for den anden. Det er måske ikke for dristigt at se begge som eksempler på (instances of), og metaforer for, den forening, som den skabende fantasi selv bringer $i$ stand. For denne sammensmeltning er ikke logisk; den bryder øjensynlig med videnskaben og den sunde fornuft; den sammenføjer det uoverensstemmende og det selvmodsigende (op. cit. 23-4; 18).

Analysen går altså ud fra det paradoks, der bestảr i på én gang at fastholde religiøsiteten og at kanonisere de elskende, og analysen munder ud i det paradoks, at de elskende ved at forsage verden i hinanden făr en hel verden. Den væsentlige formidling af disse modsætninger sker på det billedmæssige og sproglige plan, gennem pả én gang afvisning og indoptagelse af kærlighedsdigtningens billedsprog, gennem sammenføringen af det religiøse og det erotiske. Alt i alt løses altså de $i$ digtet formulerede konflikter, og de opgår $i$ en enhed, der til sidst bestemmes som (billede på) digtets enhed. Det er digterens/det digteriske sprogs "creative imagination" (18), der udvirker denne (op)løsning af modsætninger og det er herigennem digtet kommunikerer hen gennem tiden. I sidste instans læses således også dette digt som bekræftelse af forestillingen om Menneskets Mangfoldige Enhed og det digteriske sprogs, Poesiens, særlige kraft til at formidle denne enhed. Digtet drages ud af historien, læses ABSTRAKT, $i$ stedet for at blive læst ind $\mathrm{i}$ historien, at blive læst KONKRET. En sådan konkretisering kan på et vist niveau yderligere almengøres for så vidt som Donnes historie til en vis grad også er vor historie: 
Det er i kort begreb historien om adskillelsen af samfundsliv og privatliv, om etableringen af privatlivet som Menneskelighedens sfære, om helligelse af tosomheden, altså om anvendelsen af religiøsiteten som ideologisk overbygning på familie-institutionen. For så vidt berører Brooks alt dette - han loeser teksten -, idet de to centrale "paradokser", han finder, netop omhandler dels forholdet mellem kærlighedslivet og religiøsiteten dels forholdet mellem samfundslivet og kærlighedslivet. Kan Donnes digt forekomme på én gang aktuelt og mystificerende for os, så kan det hænge sammen med pả den ene side, at vores tid som hans er en brydningstid (dengang var det $\mathrm{i}$ kongens virkelige og prentede billede den kapitalistiske produktionsmåde sattes igennem - nu vakler den), på den 6 anden side, at Donnes forsøg på under henvisning til de højere sfærer at redde kærlighedslivet gennem isolering med den borgerlige ægteskabsinstitutions nedgang og fald er blevet problematiseret - sḳønt flere samtidige tendenser åbenbart peger $\mathrm{i}$ retning af Donnes løsning: isoleret (eller gruppevis) eufori under henvisning kosmos (1970'ernes brug af metafysikken).

\subsection{Digtet som iscenescettelse}

Den betragtningsmåde, som Brooks anlægger, invalideres således ikke totalt af den historiske læsning: den skærper opmærksomheden omkring metaforik, billedsprog osv, men dens religiøst-humanistiske overbygning kan ikke opretholdes. I sin søgen efter "poesiens essens" har Brooks fundet en kerne, som kan angives ved betegnelsen - hentet fra Coleridge "the balance or reconcilement of opposite or discordant qualities" (cit. efter Brooks 1963 p. 18) og som søges udfoldet gennem en række begreber, der rækker fra sproglige til bevidsthedsmæssige fænomener og munder ud i den centrale term: dramatisering, hvorudfra det poetiske sprog kan ses som iscenesættelse af holdninger, der sprogligt og intellektuelt er bundet til "wit", "paradox", "irony" og "metaphor".

En sammenfatning af synspunktet giver denne passage:

Det er måske ikke nødvendigt at påpege, at den betydning, der tillægges oplosningen af tilsyneladende antitetiske holdninger, forklarer den vægt, som på de foregående sider er lagt på 1) åndfuldhed (wit) som opmærksomhed på mangfoldigheden af mulige holdninger, der kan indtages overfor en given situation; på 2) paradoks som middel til at stille et mere inkluderende (inclusive) syn op over for det konventionelle syn på den, eller over for det begrænsede og specielle syn, som er den praktiske eller den videnskabelige diskurs' syn; og på 3) ironi som middel til at definere holdninger gennem modifikationer. (op. cit. 212; 257). 
182

Wimsatt giver denne samlende bestemmelse af Irony' i slutningen af Literary Criticism:

Det kan være nyttigt at tage 'ironi' snarest som et kognitivt princip, som gennem paradoks glider over i det generelle metafor- og metaforstruktur-princip - den spænding, som altid ligger i en væsentlig ny brug af ordene. Ironi- og metafor-brugens egentlige fordel ligger $i$ at det er en teori, der indbefatter såvel poetisk indhold som poetisk "form" og søger disse tos indbyrdes afhængighed. (Wimsatt \& Brooks, 747).

På denne baggrund bliver vurderingskriteriet dette:

Man kan derfor sammenfattende sige, at et digt ikke skal bedømmes ud fra det sande eller falske som sådant i den idé, det indeholder, men snarere ud fra dets karakter af drama - ud fra dets sammenhæng, følsomhed, dybde, rigdom og bevidsthedsmæssige styrke (toughmindedness; udtrykket er vanskeligt at oversætte, måske med urette bliver jeg mindet om en art western-kvalitet på det åndelige niveau) (op. cit. $256 ; 211$ ).

[...] vi må undersøge, om de anvendte kunstgreb (devices) - hvad enten det er idé-forløb, metafor-udvikling, eller ordvalg - medvirker til at udvikle en sammenhængende og stærk holdningsstruktur. Hvis de gør det, stemmer de overens med og retfærdiggøres af det eneste "decorum" som egentlig betyder noget. (op. cit. 207; 251).

Dette decorum er "the ultimate decorum of the realized poem itself." (smst). Det digteren giver os er

[....] en indsigt, der bevarer oplevelsens enhed, og som på et højere og alvorligere plan overvinder (tripumps over) oplevelsens tilsyneladende modstridende og uforenelige dele ved at forene dem i et nyt mønster. (op. cit. 214; 177).

Opfattelsen af poesien som inkorporerende modsatte elementer og holdninger kan føres tilbage til T.S.Eliot og I.R.Richards. Jeg vil da afslutte redegørelsen med disse to's formuleringer. Først Eliot:

(Wit) indbefatter antagelig en i udtrykket for enhver erfaring implicit erkendelse af andre mulige arter erkendelse, som vi finder lige så klart hos de største som hos digtere som Marvell. (Eliot 1958, 303).

Denne formulering ligger tæt op ad Brooks, jeg vil derfor undlade at udvikle den nærmere, men straks anføre Richards:

Impulser kan organiseres på to måder. Ved eksklusion og ved inklusion, ved syntese og ved elimination. Skønt enhver sammenhængende sindstilstand er afhængig af begge, er det tilladeligt at opstille oplevelser der får deres stabilitet og orden gennem en indsnævring af reaktionen, 
som en modsætning til oplevelser som udvider den. En meget stor del af digtningen og kunsten stiller sig tilfreds med den fulde, ordnede udvikling af forholdsvis specielle og begrænsede oplevelser med en bestemt emotion, f.eks. sorg, glæde, stolthed, eller en bestemt holdning, f.eks. kærlighed, vrede, beundring, håb, eller en bestemt stemning, f.eks. melankoli, optimisme eller længsel. Den form for kunst har sin plads i de menneskelige forhold og sin særlige værdi. [. . .] Men dette er ikke den højeste form for lyrik. [. . . ] Ligevægten mellem modsatrettede impulser, som vi mistænker for at være grundstrukturen i de fleste værdifulde æstetiske oplevelser, aktiverer langt mere af vores personlighed end det er muligt $i$ oplevelser, hvis emotioner er mere begrænsede. (Richards 1968, 212, 213;249-50, 251).

Man kan måske sige, at hvor Eliot lægger vægt på den selvavlede modsigelse, der lægger Richards vægt på den udvidelse af bevidstheden, der kan bibringes ved læsningen af lyrik. Men det er ordenen, de begge i den sidste ende lægger vægt på.

Jeg ser bort fra den kraftige brug af psykologiserende termer hos Richards (et træk som skiller ham fra Brooks) og hæfter mig med de fælles træk: for alle tre gælder, at det er harmoniseringen af tilsyneladende uforenelige fænomener de ser som poesiens funktion og/eller essens. Og for dem alle galder det ( $\mathrm{i}$ de her benyttede passager og bøger) at den historiske bevidsthed er ringe eller helt fraværende. Der er for mig at se tale om en konsekvent uddragen af poesien fra historien. For Brooks vedkommende er dette eksplicit: han finder de historiske betingede sider af fænomenet mindre væsentlige og bringer derved sig selv i selskab med alle de øvrige fortalere for litteraturen som en ahistorisk værdi, som det er Humanioras opgave at forvalte.

Helt uhistorisk er betragtningsmåden dog ikke: Brooks understreger flere gange, at der netop i vor tid er særlig brug for poesien som modvægt til den omsiggribende naturvidenskabeligt prægede tænkning. Det er ikke for ingenting Hobbes gentagne gange trækkes frem som syndebuk (især i Brooks 1965) for så vidt Brooks netop i dennes mekanistiske filosofi ser et tidligt eksempel på den tankegang, der for ham i det tyvende århundrede har fået næsten eneherredømme, når der ses bort fra poesien, som har genoptaget traditionen fra før Hobbes. Der er altså tale orn et forsvar for Mennesket mod Teknikken, og som det gælder sådanne forsvar generelt således også her: de løber en stor risiko for at blive reaktionære.

Det er da også karakteristisk, at samtidig med at Brooks opfattelse af poesiens essens $\mathrm{i}$ sin nærmere udformning er implicit reaktionær for så vidt den er ahistorisk og manifest søger bort fra enhver holdningstilkendegivelse af konkret art, så rummer den elementer, der meget vel kaı̀ føres ind i en sammenhæng, hvor de snarest bliver kritiske. Når jeg kalder teorien for 


\section{4}

implicit reaktionær så er det korrekt for så vidt forsøg på idealistisk konfliktløsning er det. Jeg understregede ovenfor at teorien kan ses som én stor udfoldelse af en kerne, der kunne formuleres som 'harmonisering af modsætninger'; det er denne kerne, der er af ideologisk art, idet den ser bort fra modsætningernes realitet eller den realitet, der ligger i deres uforenelighed. Det er vel ikke for meget sagt, at der ligger en tilsvarende kerne i den liberalistiske opfattelse af det kapitalistiske samfund: nok er der modsætninger, men de kan klares uden reelle ændringer, og desuden er en del af dem kun tilsyneladende. På det bevidsthedsmæssige plan udelukker ideen om harmonisering også åbenbart enhver fastholdelse af en oplevet modsætning, og det er på dette bevidsthedsmæssige/ideologiske plan poesiens funktion rettelig skal ses. Ved at kombinere Eliots ydre med Richards 'indre' (jvf. ovenfor) kan en mulighed for signifikante modsætninger formuleres: dem, der opstår i mødet mellem den indre 'impuls' og den ydre (samfundsmæssige, historiske) realitet. De sky-klapper, Richards taler om, kunne da meget vel fortolkes som ideologiske bevidsthedsbegrænsninger, săledes at den bevidsthedsudvidelse poesien kunne bibringe læseren samtidig ville blive en udvidelse af den kritiske bevidsthed, og en udvidelse, som ikke frembragte harmoni, men derimod skærpede modsætningen mellem oplevelsen af det indre og det ydre. I denne sammenhæng kan også kritikken af den teknificerede bevidsthed inddrages. Fra kritisk hold er den blevet betegnet som 'instrumentel fornuft' og betragtet som et led $\mathrm{i}$ den indordning under produktionsprocesserne, der ses som karakteristisk for det kapitalistiske samfund. Formentlig ville Brooks aldrig acceptere sådanne omformuleringer af hans teori, men de er ikke desto mindre nærliggende, og det er værd at bemærke, at hele den understregning af tekstens kompleksitet og billedsprogets betydning osv., som er den vigtigste del af Brooks teori, ikke nødvendigvis skal knyttes til hans værdi-forestillinger. Som sagt er teori-dannelsen tvetydig ikke mindst i denne henseende, og for sâ vidt er den typisk for 'den borgerlige ideologi', som står i det fundamentale dilemma, at den formulerer sig som gældende alles frigørelse, men samtidig skal bevare borgerskabets privilegier: Brooks teori kan ses som en teori om frigørelse af den menneskelige bevidstheds undertrykte sider (og for så vidt er den meget relevant), men denne frigørelse tvinges over $i$ en mytisk sfære, hvor den indordnes $i$ en konfliktlos, ahistorisk oplevelse af 'coherence, sensitivity, depth, richness, and tough-mendedness'.

Således vil jeg altså vurdere Brooks principielle overvejelser, men dermed er intet sagt om hans evner til analyse af poetiske tekster: der er i The Well-wrought Urn en række fremragende analyser. Men jeg vil afslutningsvis og eksempelvis citere et af de få steder, hvor han kan gribes i en politisk relevant analyse, som gælder Blake's 'London': 
How the chimney-sweeper's cry every blackening church appall. (Hvordan skorstensfejerens råb får hver mørknende (sortnende) kirke til at blegne).

Kirkemurens sortnen (mørknen) på grund af sodet blivet et tegn på den synd kirken begár ved ikke at protestere mod den u-kristelige udnyttelse af børn som skorstensfejere; sodet fra fejningen tilsudler kirkerne selv. Men Blake går videre og fremstiller det som om barnets råb havde virkning som en forbandelse, og det antydes at kirken ved råbet såvel sortner som blegner. Yderligere antyder Blake ved ordet blegnede, at råbet kaster et ligklæde over kirken, kirken er død ... (Brooks 1965, 235).

Her analyserer Brooks altså metaforstrukturen og digtets wit, hvorved han tydeliggør digtets potentielle ideologi-kritik.

\section{KRITISK DIALEKTIK. Poesien, kulturindustrien og samfundet.}

Den urørlighed, hvori genstanden her og nu er fikseret, må teorien løse op i spændingsfeltet mellem det mulige og det virkelige: for overhovedet at kunne eksistere er begge henvist til hinanden. Med andre ord: teori er uomgængeligt kritisk.

Adorno (1970)

Foreløbig har kulturindustriens teknik blot bragt det til standardisering og serieproduktion og of ret det, hvorigennem værkets logik adskiller sig fra samfundssystemets.

Horkheimer \& Adorno $\left({ }^{1} 1947,145\right)$

For den kritiske dialektik er poesien - og teorien - modsigelse; ikke modsigelse inden for rammerne af et komplekst hele, Værket eller Bevidstheden, men modsigelse af den samfundsmæssigt herskende tendens. Det er i værkets modstand mod den blotte indoptagelse af samfundet $i$ teksten det kritiske potentiel søges; denne tekst-læsning vender sig mod såvel realisme som abstrakt kritik, mod såvel den blotte gengivelse som den blotte bevidsthedsytring; for den er værket hverken en bringen det ydre ind $\mathrm{i}$ teksten eller en bringen det indre ud i teksten. Det bliver derfor denne kritiks teoretiske problem at frembringe et begreb om teksten som på én gang underlagt og overskridende den objektive tvang, teksten som frembringende objektiv protest ud fra selve sin logik, der er fremmed for den videnskabelige, men som netop fungerer i forhold til den givne samfundsmæssige tilstand. For så vidt den objektive samfundstilstand kun 
for en overfladisk betragtning er fikseret, bliver det værkets funktion gennem sin egen logik at bringe den objektive konflikt, som ligger under den samfundsmæssige overflade (og dermed også $i$ den, blot ikke umiddelbart anskueligt) til orde; men idet omfang denne tekstlæsning ser den objektive tilstand som tendentielt homogeniseret - under 'bytteværdiens og den instrumentelle rationalitets primat' -- må den i samme grad søge modsætningen i den fra samfundet fortrængte subjektivitets objektive ytring $\mathrm{i}$ værket - der er her på ingen måde tale om den individuelle subjektivitet.

Det er således konsekvent at lade en social/politisk pessimisme ledsage af en kunstdyrkelse, der sætter Kulturens højeste artikulation som sted for den samfundsmæssige, men fra realiteterne fortrængte sandhed. Og det bliver konsekvent at se kulturindustrien som den samme sandheds fortrængning fra Kulturen, således at forsvaret for sandhed bliver et forsvar for den sande kultur imod de falske kulturindustrielle produkter, hvis forfald til blot og bar reproduktion af den samfundsmæssige overflade bliver en underkastelse under samfundstvangen i tiljublingen af den forhåndenværende virkelighed. $\mathrm{Og}$ herudfra må også et begreb om socialistisk realisme som blot gengivende den samfundsmæssige tilstand kritiseres, eftersom den samfundet immanente dialektik, der skulle være realismens begrundelse, af den kritiske dialektik ses som forvist til netop kulturlivet, hvis selvrefleksion da bliver den kritiske instans - også i samfundskritiske henseende.

Som disse bemærkninger antyder må der for den kritiske dialektik være en afgørende sammenhæng mellem samfundsanalyse og tekst-analyse, kritikken må reflektere sig selv og sit emne historisk. En kritik af den kritiske dialektiks samfundsanalyse bliver derfor også en kritik af dens begreb om værket som modsigelse, men det gælder i dette tilfælde som med den angel-saksiske nykritik, at erkendelserne med fordel kan bringes $i$ anvendelse $\mathrm{i}$ en anden samfundsanaly tisk sammenhæng.

En lidt nærmere præcisering kan ske gennem sammenstilling af begreberne om poesi og kulturindustri.

\subsection{Oplysningens dialektik}

Alle midler til udvikling af produktionen slår om $\mathrm{i}$ midler til beherskelse og udbytning af producenten, lemlæster arbejderen, så han bliver et delmenneske, nedværdiger ham til et vedhæng til maskinen, tilintetgør ved hans arbejdes kval dets indhold, gør ham i samme grad fremmed for arbejdsprocessens intellektuelle potens som den bliver indforlivet videnskaben som dennes selvstændige potens; de [til undertrykkelsesmidler forvandlede produktionsmidler] forvrider hans arbejdsbetingelser, under- 
kaster ham i arbejdsprocessen det mest småtskårent hadefulde despoti, forvandler hans levetid til arbejdstid ...

Das Kapital (674)

Når kulturindustrien således utvivlsomt spekulerer i bevidsthedsog ubevidsthedsniveauet hos de millioner, den henvender sig til, er masserne ikke det primære, men noget sekundært, indkalkuleret; et vedhæng til maskineriet.

Adorno $(197051 ; 60)$

Marx' beskrivelse af lønarbejderens undertrykkelse under produktionsapparatet, således som det styres under den kapitalistiske produktionsmådes dominans, kan danne et forbindelsesled til Horkheimer og Adornos beskrivelse af 'oplysningens dialektik' (Dialektik der Aufklärung) som en bevægelse fra underkastelse til underkastelse gennem den menneskelige tankes anstrengelse for at frigøre sig fra (imaginære) naturkræfter og underlægge sig naturen. På et stade, hvor menneskene endnu ikke havde udviklet redskaber til i større målestok at beherske naturen, fremstod naturen rimeligt nok som en ydre magt med delvist ukendte styrende kræfter. Horkheimer og Adorno ser menneskehedens historie i store træk som udviklet ud fra denne tilstand i retning mod en materiel beherskelse af naturen og en ophævelse af underkastelsen under imaginære kræfter; blot er nu $\mathrm{i}$ stedet for naturnødvendighed indtrådt en samfundsmæssig nødvendighed af samme ubønhørlige karakter. Hvad der måtte være kommet til af materiel lettelse og derigennem mulighed for bevidst erkendelse og 'åndelig udvikling' opvejes af tendenser $i$ retning af 'instinkternes fiksering' ('1947', 49) og forkrøbling af fantasien (ibid.). Idet denne linje $i$ analysen understreges, fremtræder tydeligt den fare, som fremhæves af Adornos og Horkheimers kritikere: almindelig kontemplativ kulturpessimisme, der yderligere til tider tenderer mod at isolere de subjektive faktorer, at lade kulturindustrien fremstå som selvstcendig magt. Til en sådan læsning kan som modvægt føjes Adornos egen kritik af den 'empiriske sociologi':

De empiriske metoders tiltrekningskraft ligger i kravet på objektivitet. Men paradoksalt nok foretrekker de det subjektive, noe som forklares ut fra deres opprinnelse i markedsforskningen. [. . .] I alminnelighet er den empiriske sosialforsknings objektivitet knyttet til metoden og ikke til det som utforskes. [...] De empiriske metoder: sporreskjemaer, intervju og hva som måtte være mulig med hensyn til kombinasjoner og utfylling av dem, har forholdt sig selsomt likegyldige overfor den samfunnsmessige objektivitet. (Kalleberg, 81).

Men - som det også fremhæves af kritikerne - disse tendenser står ikke 
alene; Horkheimer og Adorno fremhæver selv den samfundsmæssige (objektive) realitet som grundlag for de bevidsthedsmæssige (subjektive) forhold, der udgør kulturindustriens virkefelt:

Konformismen fremtvinges af samfundets konkrete arbejdsbetingelser og ikke af den bevidste påvirkning, der yderligere skulle fordumme de undertrykte mennesker og drage dem bort fra sandheden. Arbejderens afmagt er ikke en blot og bar finte fra de herskendes side, men den logiske konsekvens af det industrialiserede samfund, hvortil den antikke skæbne under anstrengelserne med at imødegå den er blevet forvandlet. Men denne logiske konsekvens er ikke endegyldig. Den forbliver lænket til herredømmet som dets afglans og værktøj. $(1947,51)$.

I dette lille afsnit afvises således en række af de pointer, man kunne føle sig fristet - og i et vist omfang foranlediget - til at tilskrive Horkheimer og Adorno: Den bevidsthedsmæssige undertrykkelse er ikke et udslag af bevidst komplot, af en bevidst strategi fra de herskendes side; hertil må det dog føjes, at selv om 'arbejderens afmagt' ikke er en blot og bar 'finte', så er der dog historisk evidens for tilrettelagt bevidsthedspåvirkning (propaganda, indoktrinering), men dels omfatter dette 'komplot' ikke hele det relevante område, dels er en væsentlig del af bevidsthedsstyringen ikke de eventuelle styrende bevidst (bl.a. fordi ideologien rækker dybere end dens bærere er klar over), dels - og dette er det andet vigtige punkt - er den bevidsthedsmæssige påvirkning magtesløs, hvis ikke de objektive omstændigheder hjælper med ('konformismen fremtvinges af samfundets konkrete arbejdsbetingelser'). Selv den bevidste kulturindustris manipulation har ikke frie hænder, ideologien er ikke blot og bart skin, den har sin grund i væsentlige træk i samfundsformationen. Endelig rummer citatet den åbning af den kulturpessimistiske underkastelsesdialektik, der ligger i understregningen af, at den logiske konsekvens, hvormed undertrykkelsen oprettes og opretholdes, ikke er endegyldig. Der synes i Dialektik der Aufklärung at være en inkonsekvens, idet det lukkede historiesyn og åbningens mulighed står side om side; med sideblik til Marcuse kan den lukkede historie fremtræde som udslag af en art forsyndelse mod naturen, men det er ikke en gøren denne synd god igen, der fremtræder som mulighed for åbning. Den kritiske tænkning, der gennem en tanke-anstrengelse (ordet er lånt fra Adorno) bryder igennem den tilsyneladende lukning, er én mulighed som dog ingen vegne kommer alene. Adornos kritikere fremhæver 'den politiske dimension af subjekternes kollektive aktivérbarhed' og 'solidarisk, kollektiv handlen (strejke, klassekamp, råds-bevægelse)' som grundbetingelse for ophævelsen af 'samfundets band'. Således må analysen af kulturindustrien åbne sig ud mod klassekampen dér, hvor den foregår, hvis kritikken ikke - trods sit navn - skal forblive kontemplativ. 
Et problem - som også har at gøre med de netop nævnte forhold rejser sig også ud af citatet: den industrielle produktions status i forhold til den kapitalistiske økonomi (om man vil: forholdet mellem den materielle og den økonomiske tilegnelsesform). Er det den industrielle produktion som saidan, der danner grundlag for 'konfornismen' (for nu at benytte et farligt, vagt ord som betegnelse)? Eller er det den industrielle produktion, sådan som den med nødvendighed organiserer sig under kapitalismen, der er betingelsen? Spørgsmålet rækker ind i fundamentale problemstillinger og kan ikke afhandles i en parentes; her kan blot nogle bemærkninger føjes til problematikken. For det første må der skelnes inden for det, der kaldes industriel produktion. Automatisering og andre træk i den industrielle udvikling opretter i nogle sektorer tendentielt andre arbejdsvilkår, hvilket bl.a. peger i retning af ophævelsen af den atomisering, som for Marx er et essentielt træk ved maskinel produktion (anskuęligt i samlebåndsfabrikation). I selve udviklingen af produktivkræfterne kan der således ligge en tendens $i$ retning af omstrukturering af den materielle produktionssituation, altså en ændring af det fundamentale grundlag for bevidsthedsdannelsen; også den i det ovenfor anforte Marx-citat beskrevne adskillelse af åndeligt (videnskabeligt) og legemligt arbejde vil med den direkte inddragning af videnskabelig kvalifikation i arbejdsprocessen ophæves, således at den åndelige og den legemlige kraft igen sammenføjes, blot nu i et faktisk fungerende arbejdskollektiv. Ligesom arbejdets organisering da ikke længere vil bero hos kapitalens bærer, altså hos en udenfor produktionen stående instans, således vil heller ikke klassekampens organisering eksklusivt bero hos en uden for arbejdsprocessen stående instans: parti, fagforening, eller - i mindre målestok - basisgrupper, råd m.m. Jeg anfører disse forhold for at fremhæve nødvendigheden af at gå ud fra en præcis analyse af produktionsomstændighederne og ikke blot $i$ almindelighed tale om industriel produktion; men det skal samtidig understreges, at de nævnte tendenser næppe kan tænkes sat alment igennem indenfor en overskuelig fremtid, samt at den her skitserede analyse kun antyder meget generelle træk. Desuden skal det bemærkes, at arbejde af samlebåndskarakter ikke med nødvendighed har den effekt, som Horkheimer og Adorno ser som typisk. Deres analyse er på dette punkt meget abstrakt, deres styrke ligger $i$ analysen af ideologiske fænomener (for en nærmere analyse af den teknologiske udviklings betydning for klassekampen se Kurasje 2/3, 1970). Disse forhold er primært knyttet til produktionsredskaberne og kan derfor friste til en analyse, der er uafhængig af de økonomiske tilegnelsesformer, produktionsforholdene. Sådanne analyser kan man finde mange af, Marcuse er et prominent eksempel på parallel analyse af vestlig kapitalisme og sovjettisk samfundsorganisation (for nu ikke at komme stikkende med en analytisk betegnelse). Men til analysen af kapitalistisk industriel produktion hører også 
190

analysen af den kapitalistiske økonomis virkninger på arbejdsforholdene. Sådanne analyser angiver ikke blot grundlaget for kulturindustrien, men også grundlaget for kritikken af den, og er således en forudsætning for radikal kritik.

\subsection{Digtningen og sproget}

I forbindelse med lyrik skriver (taler) Adorno om at famle efter den sproglyd, hvori lidelse og drøm formæles' (Tale om lyrik og samfund, i Kritik 13, 1970) og om kulturindustrien skriver han:

Det, som overhovedet har kunnet kaldes kultur, uden at ordet blev til en frase, har altid som udtryk for lidelse og modsigelse villet fastholde ideen om et rigtigt liv, men har ikke fremstillet den blotte eksistens [...], som om den var det rigtige liv. Hvis kulturindustriens advokater hertil svarer, at den jo slet ikke leverer kunst, så er selv dette ideologi, som onsker at slippe fra ansvaret for det, gesjæften lever af. En svinestreg bliver ikke bedre af, at den selv erklærer at være det. (1970, 67).

Hvormed altså faktisk siges, at det er en svinestreg ikke at lave kunst, eller mindre drastisk, at det er en svinestreg ikke at forholde sig overskridende til den forhåndenværende virkelighed; alternativet angives i kritikken af kulturindustrien:

Tilpasning træder takket være kulturindustriens ideologi i stedet for bevidsthed: aldrig konfronteres den orden, som udspringer af den, med det, den hævder at være, eller med menneskenes virkelige interesser. (ibid.).

Herudaf kan læses to veje, som kritikken kan gå ad: dels kan det givne konfronteres med dets egne normer, ideologien sammenholdes med virkeligheden, dels kan det givne sammenholdes med det ideelle. Sidstnævnte mulighed peger $\mathrm{i}$ retning af utopisk kritik, der som sådan af gode grunde ikke har noget sted at tale ud fra. Vi er her ved endnu et prekært punkt i Adornos kritik, et punkt, der ligesom spørgsmålet om historiens lukning kan opfattes på to måder, som begge har et vist belæg hos kritikeren selv.

Hvorfra kan den utopiske kritik have sine ideer? Der kan gives to svar; artiklens slutning giver det ene:

Bliver masserne, med urette, brændemærket som masser fra oven, så er det ikke mindst kulturindustrien, der gør dem til masser, som den derpå foragter, og som hindrer dem i den emancipation, som menneskene selv ville være modne til $i$ samme grad, som tidsalderens produktive kræfter tillod den (op. cit. 70). 
Det er $\mathrm{i}$ forhold til disse i det givne latente muligheder, kritikken kan finde sted og derved undgá det utopiske, den kan sætte ind i spændingen mellem det virkelige og det mulige og den kan i den forstand blive objektiv.

Men Adorno arbejder også med et begreb om en art objektiv sujektivitet, en art menneskene iboende modstand mod undertrykkelse, en modstand som sprogligt formidlet sætter sig igennem i den gode kunst:

I det lyriske digt negerer subjektet gennem identifikation med sproget såvel sin rent monadologiske protest mod samfundet som sin blotte rolle inden for det socialiserede samfund $(1968,87)$.

I det lyriske digt sætter subjektet sig på én gang ud over sin tilpassede samfundsfunktion og sin isolation i og med dets 'opgåen' i 'sproget'. I denne æstetik står således et begreb om sproget centralt; det må straks understreges at dette begreb om 'sproget' intet har at gøre med sprogvidenskabens begreb om sprogsystemet el. lign. Sproget er øjensynlig for Adorno en instans, der er på én gang historisk specifik og inkarnerende den mod frigørelse stræbende impuls. Problemet er da at tænke noget sådant uden at operere med et fra himlen nedfaldet historiens endemål: hvordan på én gang fastholde bevidsthedens historiske betingethed og angive dens overskridende momenter? For den unge Marx var også det mulige, det rigtige, efterstræbelsesværdige, det fornuftige immanent i det virkelige (eller: den virkelige virkelighed var immanent $i$ dens uvirkelige historiske form (når jeg nu skriver fremtrcedelsesform, så er begrebsrammen antydet: modsætningen mellem f.eks. den egentlige, voesentlige menneskelighed, og dens uegentlige, historisk-foreløbige tilsyneladende realisation)):

Fornuften har eksistert til alle tider, bare ikke alltid i en fornuftig form. Kritikeren kan altså knytte an til enhver form for teoretisk og praktisk bevissthet og ut fra den eksisterende virkelighets egne former utvikle den sanne virkelighet som dens siktepunkt og endelige mål (als ihr Sollen und ihren Endzweck). (Brev til Arnold Ruge, september 1843, 1970, på tysk i 1964).

Der synes at være et slægtskab mellem sproget i Adornos forstand og Marx' her angivne fornuftsbegreb; en yderligere bestemmelse af sprogets og kunstens rolle hos Adorno kan angives ved Marx' placering af religionen:

Religionen er jo det menneskes selvbevidsthed og selvfølelse, som enten endnu ikke er blevet sig selv eller allerede har mistet sig selv igen. Men mennesket, det er ikke et eller andet abstrakt væsen, der sidder og kukkelurer udenfor verden. Mennesket, det er menneskets verden, det er stat, det er samfund. Denne stat og dette samfund frembringer religionen som en fordrejet verdensbevidsthed, fordi de udgør en fordrejet verden. Religionen [...] er den fantastiske virkeliggorelse af 
192

det menneskelige væsen, fordi det menneskelige voesen ikke ejer sand virkelighed. Kampen mod religionen er da middelbart kampen mod hin verden, hvis åndelige aroma er religionen. / Den religiøse elendighed er på en gang udtryk for og protest mod den virkelige elendighed. Religionen er den betrængte skabnings suk, den er en hjerteløs verdens hjerterørelser, den er åndløse tilstandes åndsindhold. Den er folkets opium. [...]. Kritikken af religionen rummer altså $i$ kim kritikken af den jammerdal, hvis helgenglorie religionen er. (1961, 51-2, på tysk $\mathrm{i}$ 1964).

For at knytte forbindelsen til det tidligere sagte kan en del af det oversprungne citeres: 'Fordringen om at opgive illusionerne om sin tilstand er fordringen om at opgive en tilstand som har illusioner behov! (ibid.) Religion, ideologi, illusioner er ikke noget man lægger fra sig uden videre, ligesom man heller ikke uden videre lader sig pådutte en opfattelse; under elendige omstændigheder opstår naturligt nok et behov for at se bort fra elendigheden eller at tolke den som foreløbig.

Ligesom religionen i sig rummer en protest mod de forhåndenværende forhold, således rækker også kunsten ud over sin baggrund:

Lyrik skal ikke deduceres fra det samfundsmæssige; dens samfundsmæssige indhold er akkurat det spontane, som ikke uden videre følger af de til enhver tid bestående forhold. Men filosofien - atter Hegels - kender den spekulative sætning, at det individuelle er formidlet gennem det almene og omvendt. Det betyder nu, at også modstanden mod det sociale tryk ikke er noget absolut individuelt; i denne modstand arbejder tværtimod, gennem kunstens medium og formidlet af individet og dets spontaneitet, de objektive krofter som presser en bonert og snoerende samfundstilstand ud over den selv og frem mod en mere menneskeværdig; [...] Hvis man tør tale om at lyrikken rummer et objektivt indhold, [...] - da kan man det kun, hvis det lyriske kunstværks tagen sig tilbage i sig selv, tagen sig ind i sig selv, dets distance til samfundsoverfladen (det forhold, der andre steder omtales som kunstens autonomi, pm), er samfundsmoessigt motiveret hen over hovedet på kunstneren. Det medium, hvorigennem noget sådant sker, er sproget. [...] Thi sproget er selv en dobbelthed. Gennem sine konfigurationer indoptager det ganske de subjektive stemninger i sig; [...] Men det vedbliver dog på den anden side med at være begrebernes medium ... (Adorno 1968).

Igennem sproget, der er såvel de subjektive reaktioners som de objektive omstændigheders medium, når de objektive antagonismer ind i kunsten bag om ryggen på digteren, gennem hvis mund de objektive strukturer således kommer til orde. Men lidelsen forenes med drommen i denne 
sproglyd, altså i sproget, der ikke er reduceret til rent begrebsmæssigt eller deskriptivt gennemsigtigt medium, men har beholdt sin materielle karakter:

Kunstværker har udelukkende deres storhed i artikulationen af det, som ideologien tildækker. Når de lykkes rækker de, hvad enten de vil det eller ej, ud over den falske bevidsthed. (ibid.).

Ideologien tildækker jo ikke blot de objektive omstændigheder, den forhåndenværende virkelighed, men også dens muligheder og den bevidsthed, der rækker ud over det givne. Idet subjektet objektiverer sig i det sprogligt formidlede kunstværk kommer to objektive instanser til orde: den fælles stræben ud over 'en bornert og snærende samfundstilstand' og denne tilstand i dens dobbelte karakter af virkelighed og mulighed. Ideologien dækker så at sige det gode livs onskelighed og mulighed, kunsten afdækker dem ved ikke umiddelbart at føje sig efter hverken den forhåndenværende virkelighed eller de forhåndenværende mennesker. Den sidste formulering rejser da problemet om, hvad kunsten så føjer sig efter - og hvad det er for 'en', der føjer eller ikke føjer sig. Formuleringsvanskeligheden hænger naturligvis sammen med, at der er tale om forhold, der ikke er knyttet til de enkeltpersoner, som almindeligvis optræeder som agenter i vores diskurs, det er oplagt, at det ikke er nogen løsning at oprette kunsten som agent: det må fastholdes at formuleringerne søger at gengive det forhold, at kunstværker rummer træk som ikke umiddelbart kan fores tilbage til en bevidst producent, men som naturligvis under alle omstændigheder har sin umiddelbare oprindelse hos denne producent som formidlende objektive forhold. Problemet har at gøre med det der må rejse sig i forbindelse med netop marxistisk samfundsvidenskab (og i forbindelse med psykoanalysen) og som er det kritiske i forhold til den gængse snak: intet mindre end spørgsmålet 'hvem (eller hvad) er historiens "agent"?' Dette blot for at antyde, hvordan formuleringsproblemerne har at gøre med den gængse sprogbrugs bundethed til gængse opfattelser. (jvf. Madsen 1972). Kunsten holder sig til sagen og formulerer derved dennes indre antagonismer, hvorved den bliver oprørsk $i$ forhold til det bestående, kulturindustrien derimod forflygtiger modsætninger idet den blot forholder sig til den samfundsmæssige overflade, gengiver det bestående som var det selve det gode liv:

Kulturen, som ifølge sin egen indre mening ikke blot var mennesket til vilje, men også altid gjorde indsigelse mod de stivnede forhold, det levede under, og som ærede menneskene ved det, bliver, idet den tilpasser sig dem totalt, indpasset $\mathrm{i}$ de stivnede forhold og nedværdiger mennesket dobbelt. $(1970,62)$. 


\subsection{Integrationen og den lykkelige bevidsthed}

Ovenstående indkredsning af Adornos kulturkritik og kunstsyn angår kun enkelte aspekter, som er af betydning for denne artikels emne. Kunstopfattelsen, opfattelsen af det specifikt litterære, fremgår heraf, fordi kritikken af kultur-industrien tydeligt nok netop foregår under henvisning til det, kultur-industrien ikke er, men burde være. Svinestregen består i nedbrydningen af alt det, som i og med kunsten lægger op til en radikal kritik af de herskende tilstande: kunstens høje placering må ses i perspektivet af den kraftige afstandtagen fra kulturindustrien. 'Filosofien' - vel igen Hegels håbede på en forening af subjekt og objekt - i det gode liv - vel at mærke en forsoning, der forudsatte en æendring af den virkelige elendighed, $i$ stedet er forsoningen nu opnået ved de integreredes tilpasning til elendigheden:

Menneskene er, til integrationens triumf, helt ind $\mathrm{i}$ deres inderste adfærdsmåder, identificeret med det, der sker med dem, subjekt og objekt er, i hånlig kontrast til filosofiens håb, forsonet.

Så længe virkeligheden er i konflikt med sig selv, să længe den sande menneskelighed strejfer ulykkelig og fordrejet om i en fremmed verden, skulle kunsten artikulere de virkelige antagonismer, men med kulturindustriens overtagelse af kunstens funktioner forvitrer kritikken:

På samme måde som dette samfund vil indskrænke og endda absorbere oppositionen (den kvalitative forskel!) på politikken og højkulturens område, således også på drifternes område. Resultatet er, at de åndelige organer, som skulle fatte modsigelserne og alternativerne, visner hen, og i den eneste dimension, der er tilbage i den teknologiske rationalitet, kommer den lykkelige bevidsthed til at råde. (Marcuse, 1969, 95).

Det er her Marcuse, der tager temaet op under henvisning til freudiansk analyse. Marcuses bog kan på mange punkter ses som en videreudbygning af Horkheimers og Adornos kritik, Marcuses vaklen er i øvrigt også en variant af den fremhævede tvetydighed hos Horkheimer og Adorno:

Denne tvetydige situation medfører en endnu mere grundlæggende tvetydighed. Det en-dimensionale menneske vil hele vejen igennem svinge mellem to indbyrdes modsigende hypoteser: 1) at det højtudviklede industrisamfund vil være $i$ stand til at dæmme op for kvalitative forandringer $\mathrm{i}$ overskuelig fremtid; 2) at der eksisterer kræfter og tendenser, som kan afbryde denne praksis og sprænge samfundet. Jeg tror ikke der findes et klart svar. (ibid. 15).

Og den kritik, som kan rettes mod Marcuse ud fra et marxistisk syn kan også $i$ et vist omfang gælde for Horkheimer og Adorno (selv om disse for mig at se trods alt for så vidt angår den gode side af deres tvetydighed står 
nærmere en marxistisk analyse). En kritik af Marcuse er f.eks. leveret af Thomas Krogh (i Rafoss, 1970), der hæfter sig ved det begreb om 'teknologisk rationalitet', som spiller en stor rolle hos Marcuse, og som også indgår centralt hos f.eks. Horkheimer i hans klassiske artikel om traditionel og kritisk teori (på norsk i Kalleberg) og i Dialektik der Aufklärung (tankegangen kan forfølges tilbage til Lukacs, i hvis behandling af reifikationen Max Webers bureaukrati-analyser indgår, endelig optræder et lignende synspunkt hos Simmel, f.eks. i forbindelse med beskrivelsen af 'penge-økonomien' og storby-livet, (jvf. Madsen 1971 b og Stedman Jones). En kritik af Marcuse kan kort resumeres således:

Marcuse afleder ikke sin kritik af indre modsigelser (-sætninger) i totaliteten, men bestemmer denne som irrationel; derved bliver han ikke i stand til at se en ny tilstand som udviklet af den herskende (altså en dialektisk historie), men må sætte den som en blot anden (dette hænger sammen med den rolle han tillægger teknikken som sådan, jvf, ovenfor). Den marxistiske analyse søger de overskridende potentialer $i$ den givne situation, centralt i modsætningen mellem produktiv-kræfter og produktionsforhold (mellem produktiv og økonomisk tilegnelse) for derudfra at bestemme overskridelsen(s mulighed). En-dimensionaliteten er hos Marcuse et ideologisk begreb (et begreb der angår bevidsthedsforhold); det bevidsthedsmæssige ('den menneskelige fornuft') får hos ham en primoer stilling, netop fordi han ikke afleder overskridelsens mulighed af de objektive faktorer. Hans revolutionære potentiel må derfor søges blandt de $i$ forhold til den typiske produktionsproces udenforstående, idet disse ved at være udenforstáende (relativt set) ikke er gennemsyrede af den i den herskende samfundsfunktion fremherskende af (den ikke sig selv imodsigende) teknik producerede ideologi. Godt nok har Marcuse et vist blik for modsigelserne, men hans blik sløres af hans fremherskende (teknikorienterede) forståelse, ifølge hvilken irrationaliteten er et træk ved totaliteten, og overskridelsens mulighed ikke en af helhedens indre modsætning afledet dynamik. Placeringen af modsætningen i ratio og ikke i praksis viser dette citat:

De længst fremskredne områder af industrisamfundene udviser gennemgående disse to træk: en udvikling $i$ retning af at fuldbyrde den teknologiske fornuft, og intensive bestræbelser på at begrænse denne udvikling til de etablerede institutioner. Her ligger den indre modsigelse i denne civilisation: det irrationelle element i dens rationalitet. (op. cit. 36).

Den kritik, der således kan rettes mod Marcuse, har betydelig gyldighed som kritik af også Adorno (og Horkheimer). En nøjere diskussion vil jeg tage op i en senere artikel, men et enkelt, væsentligt, punkt kan fremhæves her: I det omfang det ikke er muligt for den kritiske tanke at finde 
196

modstand mod de herskende forhold andetsteds end i kunsten og i sin egen refleksion, bliver kunsten og teorien bærere af kritikken på alles vegne. Kulturkritikken kan således emancipere sig fra de klassekonflikter, den ikke fandt, og etablere sig som samfundets almene kritiske instans. Idet klasseperspektivet tabes, lober kritikken en betydelig risiko for at blive regressivt nostalgisk; hvor den kritiske dialektik konvergerer med den konservative kulturelle jamren står den i fare for for rådelse af sit marxistiske udgangspunkt - og dermed af den historiske forståelse, der har dette som forudsætning. (For nærmere redegørelse for Adornos kunstsyn se Claus Sechers artikel i dette nr. af poetik; om frankfurterskolen og kritik heraf se Therborn 1969).

\section{TEKST-TEORI. Sproget som generator}

[...] den litterære praksis viser sig som udforskning og afdækning af sprogets muligheder.

Julia Kristeva $(1969,178)$

Som et tredje eksempel på en modsigelsens poetik kan Julia Kristevas forsøg tjene. Som $i$ de to foregående tilfælde vil jeg koncentrere opmærksomheden omkring enkelte tekster, her artiklen 'Pour une sémiotique des paragrammes' (For en paragramernes semiotik) og det forste generaliserende afsnit af artiklen 'L'engendrement de la formule' ('Formlens avling'), begge fra artikelsamlingen Semeiotikè. Recherches pour une sémanalyse, 1969, hvortil der henvises. Det er i denne sammenhæng kun muligt at komme ind på enkelte af Kristevas ideer, men dem, der bliver taget op, er centrale.

\subsection{Teksten som paragram}

Kristeva afviser alle forsøg på at forstå en teksts funktionsmåde som isoleret til selve teksten; teksten står under alle omstændigheder i forhold til andre tekster, den er skrevet $\mathrm{i}$ forhold til dem og den læses i forhold til dem, eller anderledes formuleret: teksten er en 'skrivning-læsning', en 'écriture-lecture' (181-3). Denne tekstens forholden sig til andre tekster er ikke neutral, men aktiv, for så vidt som forholdet er indoptagende og negerende. Der er således to momenter i denne opfattelse, som kan præciseres under henvisning til en i nogle henseender tilsvarende, men på afgørende punkter forskellig opfattelse, der kan findes hos T.S.Eliot i hans kendte essay om 'Tradition and the individual talent' (her citeret efter Selected Essays, 1963, 13-22):

[...] den historiske sans tvinger en mand til at skrive med ikke blot sin egen generation i blodet [is his bones], men med en folelse af, at hele 
den europæiske litteratur fra Homer og indenfor den hele hans eget lands litteratur har samtidig eksistens og udgør en samtidig orden. [...] det der sker når et nyt kunstværk skabes er noget der sker samtidig for alle de kunstværker, som er gået forud for det. De eksisterende monumenter udgør en ideal orden i sig selv, som modificeres ved at det nye (det virkelig nye) kunstværk indføjes blandt dem. (Eliot 1958, 14-15).

Og endnu et moment:

En kunstners fremskridt er en stadig selv-(op)ofring, en stadig tilintetgørelse [extinction: også ophævelse] af personligheden. (ibid. 17).

Denne opfattelse af forholdet mellem den enkelte litterære handling og traditionen rummer til trods for dens underkastelses-hyldende selvforståelse det rigtige, at den litterære produktion sker $\mathrm{i}$ forhold til andet end den individuelle skribents intentioner, og at en litterær handling er en handling, der går for sig $\mathrm{i}$ et tekstuelt rum, hvis karakter i større eller mindre grad forandres ved tilkomsten af nye tekster. Blot må det understreges, at hvor Eliot finder det virkelige kunstværks funktion i traditionens fornyelse og bevaring, dér står tilbage den mulighed at se den litterære aktivitet som destruktion af traditionen, som tekst-kritik, parodi. Det er dette aspekt, der interesserer Kristeva:

"At læse" angiver altså en agressiv deltagelse, en aktiv tilegnelse af den anden. "At skrive" ville være "at læse" som produktion, fabrikation: skrivningen-læsningen, den paragrammatiske skrift ville være en stræben efter total agressivitet og deltagelse. (Kristeva 1969, 181).

Begrebet om tekstens samtidige overtagelse og negation af andre tekster knyttes til et begreb om tekstens logik, det poetiske sprogs logik, som forskellig fra almindelig videnskabelig logik. Hvor videnskaben arbejder med et princip om, at to hinanden modsigende udsagn ikke kan være sande på én gang, der arbejder det poetiske sprog med 'dobbelthed', med samtidig affirmation og negation af et udsagn, men denne anden logik, som destruerer den videnskabelig logik, eksisterer i det poetiske sprog side om side med den 'normale' logik:

Idet tveheden [le double] således er paragrammernes mindste sekvens, viser deres logik sig at være forskellig fra den "videnskabelige logik", den monologiske, som udvikler sig i rummet 0-1 [falsk-sand] og skrider frem gennem identifikation, beskrivelse, fortælling, udelukkelse af modsigelser, etablering af sandheden. Man forstår således hvorfor grammatikkens, syntaksens og semantikkens love (som er 0-1-logikkens love, og altså de aristoteliske, videnskabelige eller teologiske) i paragrammernes dialogisme overskrides alt imens de impliceres. Denne 
198

overskidelse annoncerer - alt imens den absorberer 1'et (forbudet) det poetiske paragrams ambivalens: den er sameksistensen af en monologisk diskurs (den videnskabelige, historiske, deskriptive) og en diskurs, der destruerer denne monologisme. Uden forbuddet ville der ingen overskridelse være; uden 1 ville der intet paragram baseret på 2 være. (op. cit. 183).

For den gængse spekulative opfattelse er sproget styret af den mening, det skal videregive; i videnskabelig sammenhæng styres sproget af teoridannelsens og analysens logik; i historieskrivningen af de historiske fænomeners sammenhæng; i den fortællende litteratur af begivenhedernes mening, deres sandsynlighed eller nødvendighed (i følge Aristoteles og mange siden ham), af de handlende personers psyko-logik osv; overhovedet søger tekst-læsningen $\mathrm{i}$ almindelighed den mening, der er nedlagt $\mathrm{i}$ teksten (og $\mathrm{i}$ verden), tekst-læsningen er en hermeneutik, en tolkning, hvis principielle forbillede er læsning af Guds skrift, hvadenten det er skriften i verden (naturens orden osv) eller det er Skriften, den hellige skrift. Imod denne opfattelse står en hel del viden om, hvordan sprog også kan fungere, hvordan ikke mindst sprogets udtryksside kan bemægtige sig styringen over indholdssidens meningsfulde fremadskriden. Noget sådant sker dog fortrinsvis, hvor rationaliteten er 'sat ud af spillet': hos børn, gale og digtere, ludisk, neurotisk eller poetisk. Det er almindelig bekendt, hvordan børn 'leger med sproget', lader udtryksfænomener styre deres uansvarlige pludren (og det kan peges på, hvordan en didaktik bemægtiger sig dette fænomen til eget brug, således eksempelvis i den dobbelte logik i "Ole Bole, gik i skole"). Fra Freuds skrifter kan en række eksempler og principielle overvejelser over det sproglige udtryks funktion hentes (jvf. her Torben Grodals artikel om Tematisk tekst-analyse, i poetik IV, 4, 1972). Jeg anfører to eksempler, der begge viser, hvordan det sproglige udtryk spiller en rolle $\mathrm{i}$ forbindelse med ubevidste psykiske processer; det første er fra Hverdagslivets psykopatologi, hvor Freud i første kapitel anfører et eksempel på navne-forglemmelse og erstatningsnavn. Han kan ikke komme på en bestemt italiensk malers navn (Signorelli) og finder kun frem til de to forkerte navne Botticelli og Boltraffio; analysen viser nu, at emnet for den forudgående samtale har spillet ind: den drejede sig om nogle i Bosnien og Herzegowina boende tyrkeres fatalisme over for døden (den typiske reaktion anføres som: 'Herre, hvad skal man sige hertil...'), Freud undlader i samtalens forsættelse at fortælle om de samme tyrkeres forhold til seksualiteten; hertil kommer, at Freud kort tid forinden i Trafoi havde fảet meddelelse om, at en patient havde begået selvmord, den pågældende patient havde lidt af 'en uhelbredelig seksuel forstyrrelse'. Der er nu ifølge Freuds analyse sket det, at tanken på døden og seksualiteten forbundet med meddelelsen om den døde, seksuelt afvigende patient på den ene side 
har koblet sig sammen med størrelserne Herre og Her(zegowina) og via indholdssiden med begyndelsen af den glemte malers navn Signor(elli), hvorved dette er fortrængt, på den anden side er tankekomplekset dog trængt igennem via stednavnet Trafoi der gennem udtrykslighed har bragt det forkerte navn (Bol)trafio frem. Ligesådan har associationen forskudt sig mellem de to stednavne: fra Herzegowina til Bosnien, hvorved begyndelsen af de to erstatningsnavne er leveret: Botticelli (der yderligere har samme endelse som det rigtige navn) og Boltraffio. Freud fremstiller det hele skematisk således:

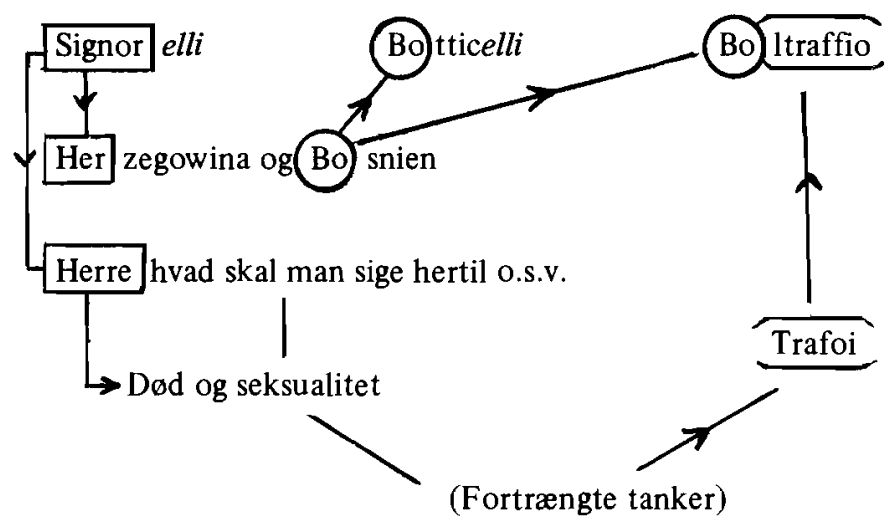

Det andet eksempel er fra Drommetydning, hvor Freud i ovrigt henter det fra en kollega, jeg nøjes her med vedkommendes eget resumé af analysen, som angår et i drømme udtalt ord, som ikke findes i sproget: erzefilisch:

Ved min Erzählung (fortælling) har jeg villet virke erzicherisch (pædagogisk) på min Erzieherin's (guvernantes) følelsesliv, men jeg er bange for, at det samtidig kan have virket forgiftende. Erzefilisch var dannet af erzählen, erzieherisch og syfilis. (Drommetydning, Kap. 6, slutningen af afsnit $\mathrm{A}$ om fortætningsarbejdet, dansk udgave 250).

Når udtryksspillet således åbenbart fremtræder i psykoanalysens erfaringer er det uomgangeligt at tage det i betragtning i tekstanalysen; selv om Kristeva $\mathbf{i}$ artiklen om paragrammerne ikke i noget større omfang henviser til Freud, men derimod i betydeligt omfang forsøger at fremstille sine ideer i matematisk sprogbrug, så er det nærliggende at sammenstille hendes betragtninger netop med Freuds erkendelser i forbindelse ikke mindst med drømmearbejdet. Selve begrebet om den manifeste drøms flertydighed, om drommelementernes flerfoldige bestemmelse, om forsky'dningen og fortæt- 
ningen som mekanismer i drømmearbejdets etablering af drømmen, alt dette peger næsten umiddelbart mod tekst-analysens praksis og mod behovet for begrebsliggørelse af sådanne tekstuelle fænomener, som ikke lader sig bringe ind under meningens primat. Som i mange andre sammenhæng må der her skelnes mellem to former for udnyttelse af fremmede teoridannelser: på den ene side må Freuds erkendelser af sproglige fænomeners forhold til det ubevidste have direkte relevans for tekst-analysen for så vidt den forholder sig til netop sproglige fænomener, på den anden side kan analysen af drømmearbejdet danne model for tekst-analysen også selv om de to former for analyse ikke skulle have emner, der er indbyrdes forbundne. I det aktuelle tilfælde må det antages at begge former for udnyttelse kan have gyldighed, men det gør det ikke mindre væsentligt at være opmærksom på hvilken form for udnyttelse der i de enkelte tilfælde er tale om.

Til oplysning om, hvad der kan menes med paragram kan en sammenstilling med parodi tjene. Parodien betjener sig af en litterært fænomen, idet dette fyldes med andet indhold, sảledes at virkningen er spottende, negerende. Gramma betyder bl.a. skrifttegn, indskrift; paragrammet er således 'parodi' på selve det skriftlige, sproglige plan. Den klassiske anvendelse af termen går snævert på sådan noget som ombytning af bogstaver ('det at skrive et Bogstav istedetfor et Andet, for Skjemt el. Spot' meddeler Bergs Groesk-Dansk Ordbog), et illustrerende eksempel: Claudius Tiberius Nero skrives Caldius (dvs. den af vin glødende) Biberius (dvs. drukkebold) Mero (dvs. vinsøber). Idet gramma anvendes som betegnelse for alle former for sproglig differentiering (differeren), såvel udtryksmæssigt som indholdsmæssigt, og idet der søges relationer sảvel imellem teksten og andre tekster som inden for den analyserede teksts rammer, bliver paragram-begrebet meget omfattende.

Hver størrelse i teksten kan tages som udgangspunkt for en række korreleringer, for oprettelsen af en række forbindelser, der for Kristeva principielt er af to arter:

Det er måske ikke for dristigt at postulere, at alle det poetiske sprogs relationer kan formaliseres ved funktioner, der på samme tid bruger to modi: negationen og afbildningen. (op. cit. 190).

Omvendt - og herved fremhæves parallellen til Freud - kan hvert element betragtes som overdetermineret, det optræder på det pågældende sted $\mathrm{i}$ teksten af flere grunde. Teksten som helhed bliver altså et net af sådanne relationer, hvori de sproglige størrelser udgør nettets knudepunkter. Et enkelt eksempel hentet fra indholdssiden kan illustrere Kristevas analyse. I artiklen diskuterer hun et lille stykke af Lautréamonts Maldorors sange:

Il y a des heures dans la vie oú l'homme, à la chevelure pouilleuse (A) jette, l'oeil fixe (B), des regards fauves (C) sur les membrames vertes de 
l'espace (D); car, il lui semble entendre devant lui, les ironiques huées d'un fantôme (E). Il chancelle et courbe la tête: ce qu'il a entendu, c'est la voix de la conscience. (cit. 186).

Dette bliver i Jørgen Sonnes oversættelse, når fortsættelsen tages med:

Der er timer i livet, hvor mennesket under det lusede hår, med øjene stive, kaster vilde blikke på himmelrummets grønne membraner; for det ér ham som han hører, foran sig, et fantoms ironiske hvin, Han vakler og bøjer hovedet: det som han har hørt, det er samvittighedens stemme. Da styrter han ud af sit hus, med en gal mands hast, vælger den første vej som byder sig for ham $i$ hans lammelse, og sluger landets buklede sletter. Men det gule fantom taber ham ikke af syne, og forfølger ham med en lignende hast. Nogle gange, i en stormnat, medens legioner af vingede blæksprutter, som fjernt fra ligner ravne, svæver oven over skyerne, imens de styrer i stiv række mod menneskenes storbyer, med den mission at vare dem om at ændre opførsel, ser flintestenen med det sørgmodige blik to skabninger passere i lynenes skær, den ene bag den anden; og mens den aftørrer en skjult medlidende tåre, der løber fra dens isnede pupil, råber den: "Visst, han fortjener det; og det er kun retfærdigt." Efter at have sagt det, stiller den sig igen i sin vilde attitude, og fortsætter $\mathrm{i}$ en nervøs rysten med at betragte jagten på manden, og de store vagina-læber af mørke, hvor der uden ophør flyder ud som en strøm, umådelige, skumle spermatozoider, der svinger sig op i den uhyggelige æther ...)

Kristeva analyserer dette stykke idet hun udskiller sem-indholdet (sem: indholds-enhed) i de med store bogstaver mærkede enheder (eller mængder):

A: corps $\left(a_{1}\right)$, poils $\left(a_{2}\right)$, chair $\left(a_{3}\right)$, sale té $\left(a_{4}\right)$, animal $\left(a_{5}\right) \ldots$

B: corps $\left(b_{1}\right)$, tension $\left(b_{2}\right) \ldots$

C: sinistre $\left(c_{1}\right)$, peur $\left(c_{2}\right)$, spiritualisation $\left(c_{3}\right) \ldots$

D: matière $\left(d_{1}\right)$, couleur $\left(d_{2}\right)$, violence $\left(d_{3}\right)$, sinistre $\left(d_{4}\right)$, abstraction $\left(d_{5}\right) \ldots$

E: esprit $\left(e_{1}\right)$, idéalisation ( $\left.e_{2}\right) \ldots$ (op. cit. 187).

A: kroppe $\left(\mathrm{a}_{1}\right)$, hår $\left(\mathrm{a}_{2}\right), \operatorname{kød}\left(\mathrm{a}_{3}\right)$, smudsighed $\left(\mathrm{a}_{4}\right)$, dyr $\left(\mathrm{a}_{5}\right) \ldots$

B: kroppe $\left(b_{1}\right)$, spænding $\left(b_{2}\right) \ldots$

C: truende $\left(c_{1}\right)$, angst $\left(c_{2}\right)$, åndiggørelse $\left(c_{3}\right) \ldots$

$D$ : det materielle $\left(d_{1}\right)$, farve $\left(d_{2}\right)$, vold $\left(d_{3}\right)$, truende $\left(d_{4}\right)$, abstraktion $\left(d_{5}\right) \ldots$

E: ånd $\left(\mathrm{e}_{1}\right)$, idealisering $\left(\mathrm{e}_{2}\right) \ldots$

Hver af de opregnede ord angiver altså en indholdsenhed i de med store bogstaver angivede indholds-mængder, den videre analyse finder nu, hvilke 
202

relationer der består mellem disse semer, en konklusion af analysen lyder: Ekvivalensen, som etableres mellem semerne i det poetiske sprogs net, er radikalt forskellige fra simple semantiske systemers ækvivalenser. Afbildningen forener mængder, som ikke er ækvivalende på primære sproglige niveauer. $\mathrm{Vi}$ har konstateret, at afbildningen forener selv radikalt modsatte semer $\left(a_{1} \equiv c_{3} ; a_{4} \equiv e_{1} \ldots\right.$ osv. $)$, der henviser til forskellige denotata, for at signalere, at disse i den litterære teksts semantiske struktur er ækvivalente. Således udarbejdes i de paragramatiske net en ny mening, der er autonom i forholdet til dagligsproget. (op. cit. 188).

Dette må sammenholdes med den indledende bestemmelse af teksten:

Denne passage - såvel som hele teksten som udgør Maldorors sange, hvorfra den er taget - er en paragramatisk realisering af en vedkendt krop, et indoptaget køn, en fantasi, der betegnes og skrives som brud med den kunstige idealisme (la conscience), og dette med al den dystre ironi, som denne sønderriven drager med sig. (op. cit. 186).

Denne sidste passage angiver ganske klart, at Lautréamonts tekst sættes i opposition til den idealistiske tradition, som den er skrevet ind i. Den har altså en specifik betydning; det forekommer vanskeligt at fastholde på én gang dette (at teksten har en specifik betydning) og tanken om, at teksten systematisk forbinder ellers uforenelige størrelser. For at komme nærmere ind på dette problem må den generaliserede typologi tages op.

\subsection{Det poetiske sprogs uendelighed og den paragrammatiske praksis}

Den generaliserede problematik kan behandles på tre områder: 1) det poetiske sprogs uendelighed, 2) den paragrammatiske praksis i almindelighed, 3) geno-tekst-begrebet.

Artiklen om paragrammets semiotik er skrevet i polemik mod en række synspunkter; ovenfor har været nævnt, hvordan analysen står i modsætning til den hermeneutiske tolkning, her skal spørgsmålet om forholdet mellem dagligsprog og poetisk sprog diskuteres. En hyppig betragtningsmåde ser poetisk sprogbrug som afvigelser fra normalsproget, idet dagligsproget sættes som norm. Sprogsystemets regler følges af normalsproget, mens det poetiske sprog bryder dem. Et andet synspunkt finder, at der i poetisk sprogbrug er tale om en indskrænkning af den dagligsproglige kode, idet der til de sædvanlige regler føjes et nyt sæt regler (metriske og andre former for udtryksmæssige regler, såvel som specifikke semantiske struktureringer). For Kristeva er det poetiske sprog en realisation af i sproget liggende muligheder, som ikke kommer til udfoldelse i daglig sprogbrug, idet denne er begrænset, censureret. Således 
bliver den poetiske sprogbrug snarere overordnet end marginal; her må dog forsøges en præcision:

For os er det poetiske sprog ikke en kode, der indbefatter [englobant] de øvrige [...] det poetiske sprog rummer [contient] den lineære logiks kode (op. cit. 178).

Den poetiske sprogbrug 'rummer' de andre koder, men 'indbefatter' dem ikke; forholdet kan måske formuleres således: dagligsproget er ikke et særtilfælde af poetisk sprog, men i poetisk sprogbrug kan dagligsprogets regler fungere sammen med andre regler. (Vanskeligheden ved at gengive Kristevas tankegang består bl.a. deri, at hun formulerer sig i matematiske termer, men dog betragter disse som metaforer (se s. 201)). Det er kun i poetisk sprogbrug alle sprogets muligheder kan realiseres.

Generaliseret fremtræder disse synspunkter i den typologi af betydende praksis, som Kristeva forsøger at opstille. Hun skelner her mellem 1) systematisk, monologisk praksis, 2) tranformerende praksis, 3) skriftpraksis, dialogisk, paragrammatisk praksis. Den systematiske, monologiske praksis er den, der søger entydigheden, beskrivelsen, logikken. Den tranformerende praksis søger at sætte et nyt system i stedet for et givet, ikke blot og bart at beskrive det, det er eksempelvis psykoanalytisk praksis. Den sidste type praksis er den, hele artiklen søger at indkredse; denne paragrammatiske praksis sætter ingen betydning uden at ophæve den igen, folger ingen lovmæssighed uden at forlade den og bryde den op, men forudsætningen for dette opbrud er, at en lov er sat.

Denne paragrammatiske praksis er formalt bestemt hos Kristeva, den bestemmes - når der ses bort fra alle forsøgene på at anvende matematisk notation og begrebslighed - rent formelt som opbrud, som modsigelse, der ophæver sig selv osv. Når denne praksis benævnes revolutionær, să må det bemærkes, at den ikke er mere revolutionær end den abstrakte anarkisme, som på samme måde påberåber sig det stadige opbrud. Den abstrakte kontestering ligger langt fra revolutionær handling, da den ifølge sit begreb overfor enhver organisering, enhver analyse, der sigter mod erkendelse af specifikke historiske forhold, må bryde op og søge andetsteds hen; den er ligesom narren lænket til sin herre, da det er ham, der skal levere den tale, det er narrens opgave at parodiere. Som ideologi-kritisk praksis har denne art protest kun en igangsættende funktion i og med den blotte modsigelse af den herskende tale; idet den blot og bart siger nej til enhver éntydighed, siger den systematisk $j a$ til flertydigheden som sådan og forbliver derfor det negative modstykke til den humanistiske søgen efter menneskets mangfoldighed.

Når der i den kristevaske teori er tale om en tiljubling af denne paragrammatiske praksis, så er det ikke mærkeligt, at historisk specificitet 


\section{4}

forsvinder ud af teorien og analysen. Ganske vist dukker den til tider op, men kun for at blive negeret igen, hvilket vel er ganske konsekvent for så vidt som det er den paragrammatiske fremfærd, og for så vidt som det understreges, at talen om den poetiske sprogbrug selv må være poetisk:

Der opstår da for semiotikeren det problem at vælge mellem tavsheden og en formalisering, som har det perspektiv, at den, idet den forsoger at opbygge sig selv som paragram (som destruktion og som maksime), bliver mere og mere isomorf med de poetiske paragrammer. (op. cit. 207).

Abstraktionen er overhovedet det karakteristiske træk ved denne teoridannelse, som i sidste instans sætter Sproget som altings ende og begyndelse; at teorien erkleerer sig dialektisk materialistisk er ingen garanti for, at den er det - misvisende betegnelser er ret hyppige i disse år. Eksempelvis:

Det ses hvordan distinktionen mellem de to termer geno-tekst/fænotekst om end den er rent didaktisk ikke mindre găr frem efter en materialistisk fremgangsmåde, som placerer strukturerings-princippet $\mathbf{i}$ selve det struktureredes materie. (op. cit. 285).

Fra et dialektisk materialistisk synspunkt er et sådant udsagn tvivlsomt så længe det ikke har gjort rede for den pågældende strukturerings indgåen $\mathrm{i}$ den samfundsmæssige sammenhæng.

Abstraktionsbevægelsen kan følges i det indledende afsnit i L'engendrement de la formule:

Indledningsvis omtales teksten - le texte - som et fænomen, der træder frem i og med den nuværende 'litteratur': "det såkaldt "litterære" arbejde opviser idag tekster", som derefter sammenlignes med "gamle hellige hymner". Det præciseres: "Teksten bliver således en bestemt type betydende produktion [production signifiante], som indtager en proecis plads $i$ historien og henhører under en specifik videnskab" (op. cit. 279). Dette er måske tvetydigt, men det forekommer nærliggende at læse det sådan, at de nævnte tekster træder frem i en bestemt historisk epoke, eftersom der var tale om det $\mathrm{i}$ begyndelsen. Men derefter siges det, at man kan finde en "tekstuel akse" i "alt hvad der er skrevet og sagt [la totalité dite et écrite]", ligesom "det specielt "tekstuelle" [la particularité "textuelle]" kan ses i enhver "effekt af sproget [effet de la langue]" (279). $\mathrm{Nu}$ indføres begrebsparret 'geno-tekst' og 'fæno-tekst', idet geno-tekst repræsenterer den "(sproglige) operation, der genererer fæno-teksten", denne operation må antages at være den "tekstuelle akse", der tidligere var tale om. Generaliseringen drives videre i denne formulering om geno-teksten: "alle de eksisterende konkrete og kommende sprogs muligheder er "givet" ["données"] for de falder maskerede og censurerede ned i 
fæno-teksten”' (284). Denne formulering peger på ligheden (identiteten) mellem begrebet om poetisk sprog og begrebet om geno-tekst. I den følgende formulering er tekst-begrebet blevet på én gang abstraheret historisk (i sammenligning med den indledende placering af 'teksterne' i den senere tid) og blevet ophøjet til begreb om åndshistoriens subjekt; der er tale om at finde ud af, "hvordan teksterne igennem tiderne har gjort sig til agenter for omformningerne af tanke-systemerne ...". Gennem denne konsekvente abstraktion ophæves en historisk materialisme som muligt fundament for analysen til fordel for en sprogorienteret objektiv idealisme.

En marxistisk analyse måtte opfatte den samlede samfundsmæssige udvikling som 'subjekt' (eller med andre ord som en 'proces uden subjekt') - så længe den historiske udvikling foregår hen over hovedet på agenterne, og den måtte som følge deraf analysere også tankeformernes ændringer $\mathrm{i}$ dette perspektiv, hvilket naturligvis ikke udelukker muligheden for specielt tekstuelle artikulationer, så lidt som det udelukker specifikt psykiske artikulationer. En tekst-teori måtte have til opgave at analysere disse faktorer i deres historiske sammenfletning - og undgå simple analogiseringer (eller homologiseringer).

Når der senere er tale om, at det først er siden 'det epistemologiske brud' i midten af forrige århundrede, at teksten er kommet til udfoldelse, og når de tidligere tekstuelle begrænsninger fortolkes som udslag af en snæver tekst-opfattelse, så flyttes åndshistoriens subjekt fra teksten selv over i sprogtænkningen og tekst-teorien (tekst-teoretikeren) er placeret som subjekt. (Om Kristevas 'semanalyse', jvf. Lykke Knudsen 1970).

\section{Konklusion}

Fælles for de her diskuterede kritikere - eller om man vil: fælles for de her diskuterede synspunkter på Poesien - er, at de netop i poesien finder det, som sætter sig op imod den fremherskende samfundsmæssige tendens. Og fælles er det, at de finder modsigelse som et centralt aspekt ved teksten. Nogle forskelle er også fremhævet: Brooks finder modsigelsen i selve teksten i dens udfoldelse af menneskets mangfoldighed og kun middelbart bliver teksten til modsigelse af samfundsmæssig realitet. Adorno finder derimod tekstens væsentlige funktion i dens modsigelse af den samfundsmæssigt fremherskende tendens, men den tendens der hos Brooks såvel som hos Adorno er tale om, er den samme: den instrumentelle rationalitet, blot er Brooks begriben af forholdet reaktionært, mens Adornos er samfundsanalytisk formidlet og derfor ikke nødvendigvis regressivt, selv om kulturpessimismen netop fordi den ingen udviklingsmuligheder finder $\mathrm{i}$ den forhåndenværende samfundssituation rummer risici for reaktionær tolkning. Reagerer disse to kritikere salledes på den samme samfundsmæssige realitet, så peger deres kritik dog ikke sammesteds hen, men deres 
samfundsmæssige placering kan næppe heller siges at være den samme. Hvor Brooks' kultursyn i sin bagudskuende karakter kan formodes at have at gøre med udviklingen i USA, hvor kapitalismen var den faktor, som destruerede syd-staternes før-kapitalistiske organisation, der har Adornos kulturpessimisme ganske åbenbart at gøre med fascismens destruktion af arbejderbevægelsen som progressiv faktor (specielt i Tyskland, men 2. verdenskrig betød i mange henseender et tilbageskridt for arbejderbevægelsen i Europa, ikke mindst for forholdet mellem intellektuelle og arbejderbevægelsen). Havde den kritiske teoris bærere indtil begyndelsen af 1930'erne kunnet forstå sig selv som den intellektuelle parallel til arbejderbevægelsens praktiske kritik af de herskende forhold - sådan som det endnu er tilfældet i Horkheimers artikel om 'Traditionelle und kritische Theorie' (i Horkheimer 1968 og Kalleberg 1971), så fandt den kritiske teori intet andet end sig selv efter at 2 . verdenskrig var afsluttet. Denne anskuelse af forholdet har $\mathrm{i}$ det mindste gyldighed $\mathrm{i}$ teorien for så vidt som teorien netop finder, at arbejderklassen er integreret $\mathrm{i}$ den kapitalistiske produktionsmåde. Den kritiske teori har - måske netop fordi den sætter intelligentsiaen som subjekt for kritikken - kunnet give inspiration til det studenteroprør, som $\mathrm{i}$ øvrigt hentede sine impulser flere steder fra. Til trods for kulturpessimismen har den således kunnet bringe kritiske indsigter ind i en ny social bevægelse, som så siden har udviklet sig videre ud fra sammenstødet med den borgerlige stats magtorganer og ud fra indtrykket af den europæiske klassekamps skærpelse i slutningen af 1960'erne.

Det er i denne situation Julia Kristevas teoretiske bestræbelser har fundet sted og det er i forhold til den de må ses. Som antydet kan deres teoretiske implikationer ses som parallel til studenteroprørets tidligere, anarkistisk prægede faser - og Kristeva henviser da også et enkelt sted til ungdomskulturens karnevalssprog som en parallel til semiotikkens bestræbelser (op. cit. 173), men i øvrigt fremtræder de teoretiske bestræbelser ikke som forbundet med den aktuelt fremtrædende praksis. Snarere forekommer den stadige fortrængning af den sociale praksis til parantetiske analogiseringer som en teoretisk begrænsning, hvis teoretiske legitimering rimeligvis hentes $i$ den althusserske insisteren på de forskellige praksis-niveauers relative autonomi, men hvis teoretiske resultat er en abstraktion, der er teoretisk invaliderende for så vidt som den marxistiske samfundsvidenskabs fundamentale forståelse af de samfundsmæssige fænomeners indbyrdes sammenfletning opgives til fordel for den blotte analogisering og henvisning. Når jeg her tillader mig at kritisere en henvisning med en henvisning, så skyldes det bl.a. at den kristevanske teoretisering synes at have denne reduktion som indre nødvendighed, men naturligvis også, at der er forskel på at henvise til en social sammenhæng som parallel og at henvise til et emnes indgåen $i$ denne sociale 
sammenhæng. Uden at jeg her kan belægge forholdet nærmere vil jeğ dog tillade mig at fremsætte den formodning, at den af Kristeva anvendte forlængelse af den marxistisk-leninistiske tradition nok kan være anvendelig $i$ en kritik af den humanistiske marxisme, men ikke nødvendigvis er det bedste udgangspunkt for en analyse af de tekstuelle formationers sammenfletning med de øvrige samfundsmæssige forhold. Ikke mindst på det område, der her er på tale, forekommer en genoptagelse af mellemkrigstidens diskussion af marxismens problemer påtrængende. Ikke sådan, at teoretikere som f.eks. Lukács og Korsch uden videre kan genoptages, men sådan at diskussionen mellem dem og den i den tid partimæssigt dominerende Marx-tolkning i sine implikationer synes at have betydelig relevans. I spørgsmålet om de tekstuelle fænomeners sammenfletning med den samfundsmæssige totalitet ligger også spørgsmålet om forholdet mellem de intellektuelle og arbejderbevægelsen, dette illustreres måske tydeligst ved Adornos kritiske teori.

I de tre diskuterede kritikeres praksis og teoridannelser ligger der det væsentlige at de påpeger modsigelsen som fundamentalt tekstuelt fænomen, ligesom der i Brooks' undersøgelser af metaforstrukturer, i Adornos refleksioner over modsætningen mellem kulturindustrielle produkter og potentielt kritiske tekster og i Kristevas teorier om tekst og intertekstualitet ligger ansatser til teoridannelser, som bragt ind i og omstruktureret $i$ overensstemmelse med en adækvat samfundsanalyse vil kunne være og har været til nytte for udviklingen af en tekst- og litteraturvidenskab. Mon alle tre teori-dannelser har deres begrænsning, som er søgt indkredset i det foregående.

Peter Madsen

(Ovenstående artikel er skrevet til en antologi redigeret af Charles Bouazis: Essals de la théorie du texte - recueil d'essais, udkommer 1972; manuskriptet er i uddrag anvendt som foredrag ved Filosofisk institut, Bergens Universitet, april 1972). 


\section{Bibliografi:}

Adorno, Th. W. 1968 Noten zur Literatur I, Suhrkamp, Frankfurt a/M (den citerede artikel er oversat til dansk i Kritik 13, 1970).

- 1969 Das Positivismusstreit in der deutschen Soziologie, Luchterhand, Neuwied und Berlin (den citerede artikel er oversat i Kalleberg).

- 1970 Ohne Leitbild. Parva Aesthetica, Suhrkamp, Frankfurt a/M (den citerede artikel er oversat i Vindrosen $2 / 3,1970$ ).

Brooks, Cl. 1963 The Wrought Urn, Harvest Books, New York (19471).

- 1965 Modern Poetry and the Tradition: Oxford U. P., N.Y.

- 1968 Poetisk struktur (oversættelse af 1963, jeg har i nogle af citaterne ændret oversættelsen), Munksgaard, København.

Eliot, T. S. 1958 Selected Essays, Faber \& Faber, London.

Erlich, V. 1965 Russian Formalism. History - Doctrine: Mouton \& c., The Hague $\left(1955^{1}\right)$.

Freud, S. u.å. Hverdagslivets psykopatologi, Reitzel, Københ.

- Drømmetydning, Reitzel, Købhvn. (flere udgaver på dansk, her citeret efter billigudgaven).

- 1968 Traumdeutung, in: Gesammelte Werke II/III, Fischer, Frankfurt a/M.

- 1969 Zur Psychopatologie des Alltagsleben, $=G$. W. IV.

Grodal, T. K. 1972 Tematisk tekst-analyse, in: poetik IV.4.

Horkheimer, M. \& Adorno, Th. W. '1947' Dialektik der Aufklärung. Philosophische Fragmente, Zerschlagt das bürgerliche Copyright, hamburg - berlin - havanna (Raubdruck), annonceret til udgivelse pà dansk 1972.

Horkheimer, M. 1968 Kritische Theorie I-II, Fischer, Frankfurt a/M (se Kalleberg).

Kalleberg, R. (ed.) 1971 Kritisk teori, Gyldendal, Oslo.

Kristeva, J. 1969 Semeiotiké. Recherches pour une sémananalyse. Seuil, Paris.

Kurasje 1970 Kampen mod lonarbejdet.

Lykke Knudsen, N. 1970 Semanalyse, in: Exil 4.

Madsen, P. 1967 Den russiske formalisme, in: Vindrosen 7.

- 1969 Ideo-lingvistik. Kritiske betragtninger over autonomi-problemer, in: häften för Kritiska studier 7-8 (og i NyS 1, 1970).

- 1970 Litteraturforskningens interesse, in: 60'ernes danske kritik (ed. S. Schou).

- 1971a Deux ou trois perspectives d'une science de la littérature, in: Revue Romane VI.2, Akademisk forlag, Købhvn.

- 1971 b Semiotik og dialektik. Bidrag til litteraturens, betydningens, bevidsthedens sociologi, Munksgaard, Købhvn. (Raubdruck, Aarhus, 1972).

- 1972 Hvad bærer teksten?, in: poetik V.1.

Marcuse, H. 1968 One-dimensional man. Studies in the ideology of advanced industrial society: Beacon Press, Boston.

- 1969 Det én-dimensionale menneske, Gyldendal, Købhvn.

Marx, K. 1961 Øgkonomi og filosofi (udv. ved Villy Sørensen).

- 1964 Die Frühschriften (ed. Landshut), Kröner, Stuttgart.

- 1969 Das Kapital. Erster Band ( = Marx-Engels Werke, 23), Dietz Verlag, Berlin.

- 1970 Verker i utvalg, Pax, Oslo.

Rafoss, S. (ed.) Marcuse. Innføring og kritikk, Tiden, Oslo.

Richards, I. A. 1961 Principles of literary criticism, Routledge and Kegan Paul, London.

- 1968 Litteraturkritikkens principper.

Stedman Jones, G. 1971 The Marxism of the early Lukács, in: New Left Review 70.

Therborn, G. 1969 Analys och kritik av Frankfurtskolen, in: häften för kritiska studier 5-6, 1969, og Frankfurt Marxism: a Critique, in: New Left Review 63, 1970.

Todorov, T. (ed.) 1965 Théorie de la littérature. Textes des formalistes russes, Seuil, Paris.

- 1971 Poétique de la prose, Seuil, Paris.

Wellek, R. \& Warren, A. 1942 etc. etc. etc. Theory of Literature.

Wellek, R. 1963 Concepts of criticism, Yale U. P., New Haven \& London.

Wimsatt, W. K. \& Brooks, Cl. 19672 Literary criticism. A short history, Vintage Books, N. Y. 